\title{
Görsel Sanatlar Öğretmen Adaylarının Eleștirel Pedagoji Konularını Öğrenmeye Yönelik Görüşleri ${ }^{1}$
}

\section{Views of Preservice Visual Arts Teachers on Learning Critical Pedagogy Issues}

\section{Buket TURHAN TÜRKKAN ${ }^{2}$, Belgin BORAN ŞENOCAK ${ }^{3}$}

\section{Makale Hakkında}

Gönderim Tarihi:28.09.2020

Yayın Tarihi:01.11.2021
Kabul Tarihi:02.10.2021

\section{Ozet}

Çalışmanın amacı, görsel sanatlar ögrretmen adaylarının eleştirel pedagojiye yönelik konuları ögrenmeye ilişkin istek ve gereksinimlerini belirlemektir. Bu çalışma, nitel bağlamda gerçekleştirilen betimsel bir araştırmadır. Araştırmanın katılımcılarını belirlemek için kolay ulaşılabilir örnekleme yöntemi kullanılmıştır. Araştırmanın katılımcılarını 2015-2016 ĕgitim-öğretim yılında, Türkiye'nin güneyinde bulunan bir devlet üniversitesinde güzel sanatlar eğitimi bölümü resim-iş ĕgitimi anabilim dalında ögrenim görmekte olan sekiz ögretmen adayı oluşturmaktadır. Araştırmanın verilerinin toplanmasında yarlyapılandırılmış görüşme tekniği kullanılmıştır. Araştırmanın verileri tümevarımsal analiz yaklaşımıyla çözümlenmiştir. Araştırmanın sonuçları doğrultusunda, öğretmen adaylarının eleştirel pedagojiye yönelik görüşlerinin genel olarak olumlu olduğu, eleştirel pedagojiye yönelik konuları ögrenmek istedikleri saptanmıştır. Bunun yanı sıra, öğretmen adaylarının, eleştirel pedagojiye yönelik konuları ögrenmenin çeşitli açılardan katkıları olacă̆ı̆ı düşündükleri, eleştirel pedagoji konularını nasıl ögrenmek istediklerine yönelik görüşleri olduğu belirlenmiştir. Araştırma sonuçları doğrultusunda çeşitli öneriler geliştirilmiştir.

\section{Abstract}

The aim of the study is to determine the willingness and needs of preservice visual $\underline{\text { Keywords }}$ Critical pedagogy, preservice visual arts teachers, view determination. arts teachers about learning the critical pedagogy issues. This study is a descriptive research conducted in a qualitative context. Convenience sampling method was used to determine the participants of the study. Participants of the study are consisting of eight preservice teachers studying at visual arts education department in a state university located in the south of Turkey in the 2015-2016 academic year. Semi structured interview technique was used to collect the research data. The data of the research were analysed with the inductive analysis approach. In line with the results of the study, it was determined that the preservice teachers' views on critical pedagogy were generally positive, they wanted to learn about critical pedagogy. Besides, it was determined that the preservice teachers thought that learning about critical pedagogy would contribute to various aspects, and they had views on how they wanted to learn critical pedagogy issues. Various recommendations have been developed in line with the research results.

Atıf için:

For Citation
Turhan Türkkan, B. \& Boran Şenocak, B. (2021). Görsel sanatlar öğretmen adaylarının eleştirel pedagoji konularını öğrenmeye yönelik görüşleri. Muğla Sitkı Koçman Üniversitesi Eğitim Fakültesi Dergisi [MSKU Journal of Education], 8(2), 471-485. DOI: 10.21666/muefd.801120

\footnotetext{
${ }^{1} \mathrm{Bu}$ çalışma, 6. Uluslararası Eleştirel Eğitim Konferansı'nda sözlü bildiri olarak sunulmuştur (Londra, İngiltere, 10-13 Ağustos 2016).

${ }^{2}$ Çukurova Üniversitesi Eğitim Fakültesi - bturhan@cu.edu.tr - ORCID: 0000-0003-2528-4022

${ }^{3}$ Çukurova Üniversitesi Eğitim Fakültesi - belginboran@gmail.com - ORCID: 0000-0003-2464-2385
} 
Eleştirel pedagoji, toplumdaki gücün ve ayrıcalığın nasıl işlediğini anlamak ve bu durumu dönüştürmek için öğrencilerin politik okuryazar olmalarını amaçlayan, toplumdaki ve ekonomideki adaletsizliklerle mücadelede toplumsal bir dönüşüm yaklaşımı olarak ele alınmaktadır (McLaren, 2005). Eleştirel pedagoji, metinlerin derinlemesine okunması, radikal sınıf uygulamalarının oluşturulması veya eleştirel okuryazarlığın teşvik edilmesi yoluyla otoriteyi sorumlu tutmaktan daha fazlasını içerir. Eleştirel pedagoji aynı zamanda öğrenmeyi sosyal değişimle, eğitimi demokrasiyle ve bilgiyi kamusal yaşama müdahale hareketleriyle bağlamakla ilgilidir (Giroux \& Giroux, 2006). Eleștirel pedagoji eğitim ve toplumsal bağlamın bütünleştirildiği bir yaklaşımdır.

Eleştirel pedagoji, öğretimin sınavlarda nasıl ustalaşılacağına veya düşük düzeyli işler elde etmeyi öğrenmeye indirgenmediği ancak akıl, anlayış, diyalog ve eleştirel katılımın tüm öğretmen ve öğrenciler için mevcut olduğu güvenli bir alan olarak görüldügü bir yaklaşımdır; etik bir referans ve eğitimciler, ögrenciler ve diğerleri için kamusal eğitimi demokratik bir toplumsal alan olarak iyileştirmek için bir eylem çağrısıdır (Giroux \& Giroux, 2006). Bunun yanı sıra eleştirel pedagoji, egemen gruplar tarafindan dayatılan değil tabandan gelen bir eğitim sisteminden yanadır. Eleştirel pedagojiye göre, standart programlar yerine öğrencilerin kendilerini özgürce ifade etmelerine olanak sağlayan öğretim programlarının geliştirilmesi önem taşımaktadır (Varlıkgörücüsü \& Şahin, 2018). Ayrıca eleştirel pedagoji ile geleneksel eğitim anlayışı arasında, öğretmen-öğrenci iletişimi ve rolleri bağlamında önemli farklılıklar bulunmaktadır. Geleneksel eğitim anlayışında, öğretmen ve öğrenci arasında hiyerarşik bir düzen bulunmakta ve öğrencilerin kendilerine sunulan bilgileri sorgulamalarına yönelik eleştirel bakış açısı geliştirilmemektedir. Geleneksel eğitim anlayışında dezavantajlı gruplar açısından eşitsizlik yaşanması da söz konusudur (Yılmaz \& Altınkurt, 2011). Bu bağlamda, eleştirel pedagojinin mevcut eğitim sistemindeki adaletsiz uygulamalara karşı çıkan, eğitim uygulamaları ile öğretmen ve öğrencinin rollerinin farklı görüldüğü bir anlayış olduğu söylenebilir.

Eleştirel pedagojinin çeşitli amaçları vardır. Eleştirel pedagoji, entelektüel kapasitenin ve insan emeğinin yabancılaşmasına meydan okumada, eğitimsel yollarla toplumsal sorunları fark etmeye odaklanmaktadır (McLaren, 2005). Eleştirel pedagoji yaklaşımının amaçlarından biri de, sorgulayıcı, özgür, eleştirel bilince sahip ve toplumsal dönüşümün aracısı olan bireyler yetiştirmektir (Kozikoğlu \& Erden, 2018). Eleştirel pedagoji, geniş kitleleri etkileyerek bireyleri toplumsal değişimin aracısı olarak yetiştirmeyi amaçlayan bir yaklaşımdır (Büyükgöze \& Fındık, 2018). Eleştirel pedagoji, eğitim politikası, eğitimde eşitsizlik, eğitim ekonomisi, demokratikleşme ve ayrımcılık gibi sorunları ele alarak eğitim sistemindeki sorunları ortadan kaldırmayı amaçlamaktadır (Sarıgöz \& Özkara, 2015). Kısacası eleştirel pedagoji, toplumsal sorunların çözümünde ve demokrasinin işleyişinde değişimin aracısı bireyler yetiştirilmesini amaçlamaktadır.

Eleştirel pedagoji, öğretmenleri ve öğrencileri, kim olduğumuzu ve nasıl yaşadığımızı etkileyen çeşitli kişisel ve politik sistemler arasındaki mantıksal bağlantıları birlikte keşfetmeye teşvik eder (Yokley, 1999). Bunun yanı sıra eleştirel pedagoji, hem öğretimi bilgilendiren değerler hakkında özeleştiri uygulamasına hem de öğrencileri sınıflarda karşılaştıkları bilgi ve değerlere yönelik yansıtıcı düşünmeleri için analitik becerilerle donatmanın ne anlama geldiğine dair eleştirel bir öz farkındalığa yatırım yapmaktadır (Giroux, 2010). Eleştirel pedagoji, ayrıca, öğrencileri, sağlam bir demokrasiye olanak sağlayan bireysel ve toplumsal aracılık biçimleri için koşullar yaratmaya teşvik eder (Giroux \& Giroux, 2006). Böylesi bir pedagoji, öğrencilerin metinleri ve farklı anlaşılabilirlik tarzlarını kavramaları için gerekli koşulları sağlamaya çalışmakla kalmaz, aynı zamanda onlara daha iyi ahlaki yargılarda bulunmaları için yeni yollar açar ve bu da bu yargıların 1şı̆̆ında diğerlerine karşı bir sorumluluk duygusu üstlenmelerini sağlar (Giroux, 2010). Buradan yola çıkılarak, eleştirel pedagojinin eğitimsel ve toplumsal bağlamda pek çok katkısı olduğu söylenebilir.

Eleştirel pedagoji, bilgiyi, geleneksel eğitim anlayışından farklı bağlamda ele alır. Eleștirel pedagoji eğitimde hangi bilginin öğretildiğine ya da üretildiğine eleştirel açıdan bakar (Yokley, 1999). Eleştirel pedagojiye göre bilgi, doğru olup olmamasından ziyade ezici olup olmaması bağlamında ele alınmalıdır. Eleştirel pedagojiye göre, okul bilgisi yansız ve nesnel değildir, belirli yollarla düzenlenip yapılandırılır ve toplumsal kökleri olan çıkar bağımlı bir niteliğe sahiptir (Yıldırım, 2011). Eleştirel pedagoji, belirli kurumsal bağlamlarda bilginin üretimi, dağıtımı ve tüketimi yoluyla gücün nasıl işlediğini anlamaya çalışır ve öğrencileri bilgili bireyler ve sosyal aracılar olarak yetiştirmeyi amaçlar (Giroux, 2010).

Eleştirel pedagoji, eğitimin amacını sorgulayan, eğitimde karşılaşılan sorunları tartışan, sosyal adalete önem veren, toplumsal ve eğitimsel bağlamdaki eşitlik üzerine odaklanan, sorunları toplumsal, politik, felsefi yönleriyle ele alan ve eğitimde özgürleşmenin ön plana alındığı bir yaklaşımdır (Sarıgöz \& 
Özkara, 2015). Eleştirel pedagoji yaklaşımına göre öğretmen, belirli nitelikleri veya erdemleri sürekli iyileştirmeye ve geliştirmeye çalışan bir profesyoneldir. Öğretmenin kendini her gün yenileme kapasitesi çok önemlidir. Bu ise aklın bürokratikleşmesini engeller (Freire, 1985). Eleştirel pedagojide, baskın öğretim tarzlarından farklı olarak, eğitimcilerin temel görevlerinden biri, geniş bir demokratik projenin parçası olarak, akıl, özgürlük ve eşitlik değerleri ile eleştiri ve olasılık söylemlerinin değişme işlevi gördüğü toplumsal açıdan daha adil bir dünya oluşturmaktır (Giroux, 2010). Eleştirel pedagoji, eğitim sisteminde eğiten ile eğitilen arasındaki hiyerarşik ilişkiye karşı çıkar ve eğitimde özgürleşmeyi temel alır (Balcı \& Kocabaş, 2020). Eğitimcilerin görevi, hayallerini öğrencilere empoze etmek değil; sadece eleştirmekten öte öğrencilerin kendi hayallerine sahip olmaları, kendi seçimlerini tanımlamaları için onları zorlamaktır (Freire, 1985). Eleştirel pedagoji yaklaşımını benimseyen öğretmenler, eğitim sistemine, öğretim programlarına ve ders kitaplarına eleştirel bir bakış açısıyla yaklaşmaktadırlar ve bu bağlamda eleştirel pedagoji, öğretmenlerin ve öğretmen adaylarının eğitimde karşılaştıkları sorunları belirlemeye ve çözmeye yardımcı bir eğitim argümanı olarak nitelendirilmektedir (Aksakallı, 2019). Ancak ülkemizde yapılan araştırmalarda öğretmenlerin, eleştirel pedagoji ilkelerine ilişkin tutumlarının orta düzeyde olduğu belirlenmiştir (Balcı \& Kocabaş, 2020; Büyükgöze \& Fındık, 2018). Buradan yola çıkılarak, ülkemizde öğretmenlerin eleştirel pedagojiyi ve eleştirel pedagojinin ilkelerini kısmen benimsedikleri söylenebilir ki eleştirel pedagojiye yönelik bilgi sahibi olup olmadıkları da sorgulanabilecek bir durumdur.

Öğretmenlere yönelik yapılan söz konusu bu çalışmaların yanında öğretmen adaylarına yönelik çalışmalar da yapılmıştır. Bu bağlamda öğretmen adaylarının eleştirel pedagoji ilkelerine katılım düzeylerinin orta düzeyde olduğunu belirleyen çeşitli araştırmalar bulunmaktadır (Kozikoğlu \& Erden, 2018; Şahin, Demir \& Arcagök, 2016; Yılmaz \& Altınkurt, 2011). Bu çalışmalar doğrultusunda, ögretmenlerle benzer şekilde, öğretmen adaylarının da eleştirel pedagoji ilkelerini kısmen benimsedikleri görülmektedir. Yine öğretmen adaylarının da eleştirel pedagojiye yönelik bilgi düzeyleri bilinmemektedir. Yapılan çalışmalarda, öğretmen adaylarının lisans eğitimleri boyunca yaratıcı, sorgulayıcı ve eleştirel düşünme becerilerini geliştirici ders ve etkinliklerin yapılması (Şahin, Demir \& Arcagök, 2016), eleştirel pedagoji ve eşitliğe yönelik farkındalığın arttırılması için öğretmen eğitiminde düzenlemeler yapılması (Büyükgöze \& Fındık, 2018), öğretmen eğitiminde hem lisans düzeyinde ve lisansüstü düzeyde hem de hizmet içi bağlamda eleştirel pedagojiye yönelik eğitim ve dersler düzenlenmesi (Sarıgöz \& Özkara, 2015), eleştirel pedagoji gibi eğitim anlayışlarına yönelik bilgi sahibi olunması açısından öğretmen eğitimi programlarına bu bağlamda seçmeli veya zorunlu derslerin eklenmesi (Kozikoğlu \& Erden, 2018), öğretmen adaylarının eğitim sistemlerine eleştirel bir bakış açısıyla yaklaşmaları için öğretmen eğitiminde Eleştirel Pedagoji derslerinin konulması (Balcı \& Kocabaş, 2020) önerilmektedir. Öğretmen eğitiminin, ayrıca, eleştirel pedagojinin temel alanlarından biri olarak görülmesi de söz konusudur (Balc1 \& Kocabaş, 2020). Bu bilgiler 1şı̆̆ında, öğretmen eğitiminde eleştirel pedagojiye yönelik konuları öğrenmeye yönelik bir ihtiyaç olduğu söylenebilir.

Günümüzde eğitim sistemindeki sorunların belirlenmesinde ve sorulara cevap aranmasında öğretmen eğitimi bağlamında eleştirel pedagojinin yeri ve önemi yadsınamazdır (Aslan, 2014). Özgürlüğü benimseyen öğretmenler yetiştirmek için ilk olarak öğretmen adaylarının mevcut eğitim sistemini ne kadar tanıdıkları ve eleştirel pedagoji ilkelerine yönelik görüşlerinin belirlenmesi önem taşımaktadır (Yılmaz \& Altınkurt, 2011). Bu bağlamda öğretmen adaylarının eğitim sistemine ve eleştirel pedagoji konusuna yönelik görüşlerinin belirlenmesi önemli görülmekte ve alan yazında eleştirel pedagojiye yönelik çalışmaların sınırlı sayıda olduğu belirtilmektedir (Şahin, Demir \& Arcagök, 2016). Buradan yola çıkarak, öğretmen adaylarının eleştirel pedagojiye yönelik görüşlerinin belirlenmesine yönelik bir gereksinim olduğu söylenebilir.

Eleştirel pedagoji, eğitime eleştirel bir bakış açısıyla bakan bir yaklaşım olarak tanımlanabilir. Bununla birlikte, bireyin özgürleşmesini, bireylerin bilgiyi üretmede sorgulayıcı bir yolla hareket etmesini ve bireylerin eleştirel bilinç kazanmaları gerektiğini savunan bir görüş olarak da düşünülebilir. Eleştirel pedagoji, eğitim sistemini, toplumsal, felsefi, kültürel ve ideolojik boyutlarıyla eleştirerek eğitim sistemindeki sorunların belirlenmesini ve sorunlara yönelik çözümler üretilmesini sağlayan bir bakış olarak da ele alınabilir. Eğitim sistemindeki sorunların belirlenmesi, sorunlara yönelik çözümler üretilmesi ve mevcut eğitim sistemini daha iyi hale getirmek için eleştirel pedagoji önem taşımaktadır. Bu bağlamda, eğitim sisteminde aktif rol oynayacak öğretmen adaylarının eğitim sistemini iyileştirmesi bakımından bu bakış açısına sahip olmaları önemli görülmektedir. Bununla birlikte, özgür düşüncenin işe koşulması gerektiği bir alan olan görsel sanatlar eğitiminde eleştirel pedagoji yaklaşımı ayrı bir önem 
taşımaktadır. Görsel sanatlar öğretmen adaylarının eleştirel pedagojiye yönelik konuları bilmeleri, gelecekteki öğrencilerinin yaratıcılıklarını ortaya çıkarmada özgür düşünmeleri ve eleştirel bakış açılarına sahip olmaları açısından önemlidir.

Çağımızda en önemli değişimlerin yaşandığı alanlardan biri iletişim alanıdır ve küresel kültürde metne dayalı iletişim yerini, görsellik içeren iletişime bırakmaya başlamıştır. Bu değişim süreci ise görsel sanatlar eğitimini yeniden düşünmeyi gerektirmektedir (Mamur, 2014). Görsel sanatlar eğitimi veren kurumlarda geleneksel eğitim anlayışından ziyade özgürleştirici bir anlayışla derslerde sanatın doğasını yeniden düşünmenin gerekliliği dile getirilmektedir (Güven \& Aytekin, 2016). Bu doğrultuda bir görsel sanatlar öğretmeninin çalışma için imge seçimi; dersin temasını, içeriğini ve politik doğasını belirleyen son derece önemli bir faktördür (Yokley, 1999). Bu bağlamda, görsel sanatlar eğitiminde yapılan etkinliklerin seçiminin ve gerçekleştirilen uygulamaların önemi ortaya çıkmaktadır.

Eğitim açık bir sistem olduğundan görsel sanatlar eğitiminin günümüzde meydana gelen toplumsal, teknolojik, sanatsal ve kültürel değişimlere göre şekillendirilmesine ihtiyaç duyulmaktadır (Mamur, 2014). Bu bağlamda eleştirel pedagojinin ilkeleri açısından görsel sanatlar eğitiminde alternatif bir anlayış oluşturulabileceği belirtilmektedir (Güven \& Aytekin, 2016). Eleştirel pedagoji, üretim ve değişim yerleri olarak sınıflara ve diğer alanlara -özellikle popüler kültüre- odaklanır; eleştirel pedagojiyle bütünleştirilen sanat eğitimi uygulamasının, popüler kültürün analizi ve yorumu, öğrencileri belirli ve önemli tarihsel, sosyal ve ekonomik sorunlarla yüzleşmeye teşvik etmesi gerektiği belirtilmektedir (Tavin, 2003). Eleştirel pedagoji, görsel sanatlar öğretimine yönelik kapsamlı bir yaklaşımı, estetik ve sosyo-politik amaçlara yönelik olarak farkındalığı eyleme geçirmek için sanat ve sanat eğitiminin gücünü uygulayan eleştirel bir pedagoji ile birleştirir. Bu kapsamda arttırılmış estetik duyarlılık ve takdir; zengin görsel imgenin anlam katmanlarını anlamanın ve kültürel eleştiri gerektiren kişisel fikirlerin uygulanmasının sonuçlarıdır (Yokley, 1999). Eleştirel pedagoji, kuram ve uygulamaya yönelik bakışı, toplumsal ve kültürel eylemlerle ilişkisi açısından görsel sanatlar eğitimi için önem taşımaktadır (Güven \& Aytekin, 2016). Görsel sanat derslerinde eleştirel pedagoji ile öğrenciler ve görsel sanat öğretmenleri, fikirsel oluşumları ve aslında yaşamın tüm yönlerini sorgulayarak sanatsal araçların gücünü eylemle birleştirir (Yokley, 1999). Bu açıklamalardan yola çıkılarak, görsel sanatlar eğitiminde eleştirel pedagojiye yönelik konulara yer vermenin önemli görüldüğü düşünülmektedir.

Hem sanat eğitiminde hem de eleştirel pedagojide neyin bilgi ve zeka olarak sayıldığına bakmak aynı derecede önem taşımaktadır (McKenna, 1999). Görsel sanatlarda düşünen bireylerin yetiştirilmesinde eleştiri önemlidir (İşler, 2005; Karabulut, Karakuzu \& Konca, 2008; Mercin \& Alakuş, 2005). Benzer şekilde, eleştirel pedagoji yaklaşımında da eleştiri yapmak önemli bir unsurdur. Bu bağlamda görsel sanatlar eğitimiyle eleştirel pedagoji yaklaşımı arasında yakından bir ilişki vardır ve bu iki bağlam bütünleştirildiğinde görsel sanatlar eğitiminde yapılan uygulamalar hem eğitsel hem sanatsal hem de toplumsal açıdan öğrencilere yararlar sağlayacaktır. Bununla birlikte, ülkemizde sanat eğitimi ve eleştirel pedagoji anlayışını inceleyen çalışmaların az sayıda olduğu dile getirilmektedir (Güven \& Aytekin, 2016). Ayrıca, eğitim araştırmaları bağlamında eleştirel pedagojiye yönelik daha fazla sayıda ve derinlemesine araştırmalar yapılarak sonuçların mevcut eğitim sistemiyle bütünleştirilmesi önerilmektedir (Balcı \& Kocabaş, 2020). Eğitim araştırmalarının bir parçası olan görsel sanatlar eğitimine yönelik yapılan araştırmalarda da bu öneri geçerlidir. Bu doğrultuda görsel sanatlar eğitiminde eleştirel pedagoji ilkelerini yansıtacak kişiler bugünün öğretmenleri ile yarının öğretmenleri olan öğretmen adaylarıdır. Bu bağlamda görsel sanatlar öğretmen adaylarının eğitiminde eleştirel pedagoji konusuna yer vermeye yönelik mevcut durumun ve öğretmen adaylarının eleştirel pedagoji konusuna ve bu konuyu öğrenmeye yönelik görüşlerinin belirlenmesinin hem görsel sanatlar eğitimi uygulamaları hem de görsel sanatlar alanında yapılan araştırmalar için önemli olduğu düşünülmektedir. Bu görüşler doğrultusunda araştırmanın amacı, görsel sanatlar öğretmen adaylarının eleştirel pedagojiye yönelik konuları öğrenmeye ilişkin istek ve gereksinimlerini belirlemektir.

\section{Yöntem}

Bu çalışma, nitel bağlamda gerçekleştirilen betimsel bir araştırmadır. Betimsel araştırmalar bir olguyu basit bir şekilde betimlerler ve betimsel araştırmalar genellikle bir alana yönelik ilk incelemelerde kullanılır (McMillan, 2004). Bu çalışmada, görsel sanatlar alanında eleştirel pedagoji konularının öğretimine yönelik bir araştırmanın ilk basamağını oluşturmaktadır ve bu bağlamda öğretmen adaylarının eleştirel pedagojiye yönelik konuları öğrenmeye ilişkin görüşleri betimlenmeye çalışılmıştır. Araştırmanın katılımcılarını belirlemek için kolay ulaşılabilir örnekleme yöntemi kullanılmıştır. 
Katılımcıların belirlenmesinde, görsel sanatlar eğitimi alanında öğrenim gören ve bu çalışmaya katılmaya gönüllü olma ölçütleri göz önünde bulundurulmuştur. Katılımcılar, araştırmacıların görev yaptığı fakültede öğrenim gördüklerinden kolay ulaş1labilir örnekleme yöntemine başvurulmuştur. Katılımcıların belirlenmesinde gönüllülük esas alındığından katılımcılar sekiz görsel sanatlar öğretmen adayı ile sınırlı kalmıştır. Katılımcıların beşi erkek, üçü kadındır. Araştırmanın katılımcıları 2015-2016 eğitim-öğretim yılında, Türkiye'nin güneyinde bulunan bir devlet üniversitesinde güzel sanatlar eğitimi bölümü resim-iş eğitimi anabilim dalında öğrenim görmekte olan üçüncü ve dördüncü sınıf ögrencilerinden seçilmiştir. Katılımcıların beşi üçüncü sınıfta, üçü dördüncü sınıfta öğrenim görmektedir. Üst sınıflarda öğrenim gören öğretmen adaylarının eğitime ve eğitim sistemine yönelik alt sınıflarda öğrenim gören öğretmen adaylarına göre daha fazla bilgi sahibi olmaları (Y1lmaz \& Altınkurt, 2011) görüşünden hareketle katılımcılar üçüncü ve dördüncü sınıflardan seçilmiştir. Araştırmaya katılan kişilerin gizliliği için öğretmen adaylarına GSÖ1, GSÖ2, GSÖ3, .. şeklinde kod isimler verilmiştir. Katılımcı öğretmen adaylarına görüşmeden önce eleştirel pedagojiyle ilgili detaylı bilgi verilmiştir.

Araştırma verilerinin toplanmasında yarı yapılandırılmış görüşme tekniği kullanılmıştır. Yarı yapılandırılmış görüşme tekniğinde, araştırmacı tarafından hazırlanan sorular üzerinde yanıtlayıcının kısmen düzeltme ve düzenleme hakkı yer almaktadır ve yapılandırılmış görüşmeye göre daha esnek olduğu söylenebilir (Sönmez \& Alacapınar, 2011). Yarı yapılandırılmış görüşme tekniğinde, görüşülenin kendini ifade etme imkanı, gerektiğinde derinlemesine bilgi sağlama olanağı vardır ve hem sabit seçenekli yanıtlamayı hem de bağlama yönelik derinlemesine bilgi etmeyi içermektedir (Büyüköztürk, Kılıç Çakmak, Akgün, Karadeniz \& Demirel, 2011). Bu avantajlarından dolayı yarı yapılandırılmış görüşme tekniği kullanılmıştır. Bu süreçte önceden hazırlanan sabit sorular, zaman zaman ek sorularla desteklenmiş ve derinlemesine bilgi almak amaciyla gerektiğinde, sorulara yönelik ek açıklamalar yapılmıştır.

Araştırma verileri, araştırmacılar tarafından geliştirilen ve uzman görüşünün alındığı bir görüşme formu aracılığıyla 2015-2016 eğitim-öğretim y1lı bahar yarıyılında yüz yüze görüşme yapılarak toplanmıştır. Görüşmeler ses kayıt cihazıyla kaydedilmiş, daha sonra bu ses kayıtlarının yazılı dökümleri yapılmıştır. Görüşmeler, verileri toplayan araştırmacının ofisinde yapılmıştır. Görüşmeler ortalama on dört dakika sürmüştür. Araştırmanın verileri tümevarımsal analiz yaklaşımıyla çözümlenmiştir. Tümevarımsal analiz, örüntülerin, kategorilerin ve temaların keşfedilmesin içerir ve analiz sürecinde araştırmacının veriyle etkileşimi aracılığıyla verilerden çıkar (Patton, 2002). Araştırmada da öncelikle yazılı hale getirilmiş görüşmelerde kodlamalar yapılmış daha sonra ilgili kodlar bir araya getirilerek tema ve alt temalar oluşturulmuştur. Tümevarımsal analiz tamamlandıktan sonra güvenirlik çalışmasına geçilmiştir. Verilerin analizinin güvenirliğine yönelik uzman incelemesi tekniği kullanılmıştır. Bu doğrultuda iki araştırmacı, ayrı ayrı kodladıkları verileri karşılaştırmışlardır. Karşılaştırmadan sonra uyuşmayan kod ve temalara yönelik bir araya gelerek uzlaşma sağlamışlardır. Bu uzlaşma sonrasında verilerin analizi sonlandırılmıştır. Araştırmanın geçerlik ve güvenirliğine yönelik ayrıca araştırmanın ayrıntılı betimlenmesine ve raporlaştırılmasına özen gösterilmiş, araştırmacı etkilerini kontrol etmeye yönelik araştırma boyunca önyargı, deneyim ve eğilimlerin araştırmanın dışında tutulmasına çalışılmıştır. Bunun yanı sıra, kayıtların teknik kalitesi ve transkriptlerin niteliği kapsamında ise veri kaybı yaşanmaması adına kullanılan ses kayıt cihazı görüşmeden önce kontrol edilmiş, görüşmelerin transkriptleri ise diğer araştırmacı tarafından kontrol edilmiştir.

\section{Bulgular}

Araştırmanın bulguları, öğretmen adaylarının eleştirel pedagojiye yönelik görüşleri, öğretmen eğitiminde eleştirel pedagojiye yer verilme durumuna yönelik görüşleri, eleştirel pedagojiye yönelik konuları öğrenme isteğine ilişkin görüşleri, eleştirel pedagojiye yönelik konuları öğrenmenin olası etkilerine ilişkin görüşleri, öğretmen eğitiminde eleştirel pedagojiye yönelik konulara yer verilmesine ilişkin önerileri, görsel sanatlar ve eleştirel pedagoji arasındaki ilişkiye yönelik görüşleri ve görsel sanatlar eğitimine yönelik eleştirileri olmak üzere yedi tema altında toplanmıştır. İlk olarak, öğretmen adaylarının eleştirel pedagojiye yönelik görüşleri Tablo 1'de sunulmuştur. 
Tablo 1

Öğretmen Adaylarının Eleştirel Pedagojiye Yönelik Görüşleri

\begin{tabular}{|c|c|c|}
\hline Tema & Alt Temalar & Kodlar \\
\hline \multirow{7}{*}{$\begin{array}{c}\text { Eleştirel } \\
\text { Pedagojiye } \\
\text { Yönelik } \\
\text { Görüşsler }\end{array}$} & \multirow{4}{*}{$\begin{array}{c}\text { Gerekliliğine } \\
\text { Yönelik Görüşler }\end{array}$} & Ülkemiz eğitim sistemi için gerekli görme \\
\hline & & Eksiklikleri belirlemek ve iyileştirmek için gerekli görme \\
\hline & & Eğitimdeki mevcut durum nedeniyle gerekli görme \\
\hline & & Öğretmenin bilmesi gerektiğini düşünme \\
\hline & \multirow{3}{*}{$\begin{array}{c}\text { Kendi Bakış } \\
\text { Açısına Yönelik } \\
\text { Görüş̧ler }\end{array}$} & Kendi savunduğu anlayışla örtüşme \\
\hline & & Eğitime eleştirel pedagoji penceresinden baktığını fark etme \\
\hline & & Sorgulamaya dayalı olmasını beğenme \\
\hline
\end{tabular}

Tablo 1'de görüldüğü üzere öğretmen adaylarının eleştirel pedagojiye yönelik görüşleri gerekliliğine yönelik görüşler ve kendi bakış açısına yönelik görüşler olmak üzere iki alt tema altında toplanmıştır. Eleştirel pedagojinin gerekliliğine yönelik görüşler teması altında öğretmen adayları ülkemiz eğitim sistemi için gerekli görme, eksiklikleri belirlemek ve iyileştirmek için gerekli görme, eğitimdeki mevcut durum nedeniyle gerekli görme ve öğretmenin bilmesi gerektiğini düşünme olmak üzere dört görüş sunmuşlardır. Kendi bakış açısına yönelik görüşler teması altında öğretmen adayları, kendi savunduğu anlayışla örtüşme, eğitime eleştirel pedagoji penceresinden baktı̆̆ını fark etme ve sorgulamaya dayalı olmasını beğenmeye yönelik görüşlerini sunmuşlardır. Bu tema altında GSÖ5, "Tam olarak aynı şeyi düşünüyormuşum. Yani bir anlamda savunduğum şeymiş ama ismini bilmiyormuşum. Hemen hemen söylediği her şeye katıllyorum. Az önce verdiğiniz bilgilerin hepsine katıllyorum. Aynı yaklaşımı güdüyorum ..." diyerek kendi savunduğu anlayışla örtüştüğünden söz etmiştir. Öğretmen adaylarının öğretmen eğitiminde eleştirel pedagojiye yönelik konulara yer verilmesine ilişkin görüşleri Tablo 2'de verilmiştir.

Tablo 2

Öğretmen Adaylarının Öğretmen Ĕgitiminde Eleștirel Pedagojiye Yer Verilme Durumuna Yönelik Görüşleri

\begin{tabular}{cl}
\hline \multicolumn{1}{c}{ Tema } & Kodlar \\
\hline Ö̈̆gretmen Eğitiminde Eleştirel & Yer verilmeme \\
\cline { 2 - 2 } Pedagojiye Yer Verilme Durumu & Sadece değinilme \\
\cline { 2 - 2 } & Öğretim elemanlarının eğitimi eleştirmeye değinmeleri \\
\hline
\end{tabular}

Bu temada, yedi öğretmen adayı öğretmen eğitiminde eleştirel pedagoji konularına yer verilmediğini belirttiği, bir öğretmen adayının sadece değinildiğinden, bir öğretmen adayı ise öğretim elemanlarının daha çok eğitimi eleştirmeye değindiklerinden söz ettiği görülmüştür. Bu tema kapsamında GSÖ7, "Hiç birinde yani ĕgitim derslerinin tamamında görmedim bunu ve zaten eğitim derslerimizin çoğu da çok boş geçmiştir. Acı gerçek.” diyerek derste bu konulara yer verilmediğini dile getirmiştir. Bununla birlikte GSÖ3 ise, "Tam olarak olmasa da dolayl yoldan değinen konular oldu." diyerek bu konulara sadece değinildiğinden söz etmiştir. Ayrıca GSÖ1, "Şöyle olabilir dersi işleyen ögretmen şöyle söylemiş olabilir: Takıldığını yerde ya da hayır bu böyle olmaz, böyle olmalı dediğiniz yerde, bize söyleyin dediler yani aslında bu da bir yerde eğitimi eleştirmek oluyor." diyerek öğretim elemanlarının eğitimi eleştirdiklerini belirtmiştir. Öğretmen adaylarının eleştirel pedagojiye yönelik konuları öğrenme isteğine ilişkin görüşleri Tablo 3 'te sunulmuştur. 
Tablo 3

Öğretmen Adaylarının Eleştirel Pedagojiye Yönelik Konuları Öğrenme İsteğine İlişkin Görüşleri

\begin{tabular}{|c|c|c|}
\hline Tema & Alt Temalar & Kodlar \\
\hline \multirow{11}{*}{$\begin{array}{c}\text { Eleştirel } \\
\text { Pedagojiye } \\
\text { Yönelik Konuları } \\
\text { Öğrenme İsteği }\end{array}$} & Öğrenme İsteği & Öğrenmek isteme \\
\hline & \multirow{6}{*}{$\begin{array}{l}\text { Öğrenme İsteğine } \\
\text { İlişkin Eğitime } \\
\text { Yönelik Nedenler }\end{array}$} & $\begin{array}{l}\text { Öğretmenlikte yaklaşıma } \\
\text { yapacak olma }\end{array}$ yönelik uygulamalar \\
\hline & & $\begin{array}{l}\text { Öğretmenlikte yararlı olacak ve öğretmenlerin sahip } \\
\text { olması gereken bir yaklaşım }\end{array}$ \\
\hline & & $\begin{array}{l}\text { Ezberci öğretmen adaylarının kalıp dışına çıkabilecek } \\
\text { olması }\end{array}$ \\
\hline & & Eğitimin geliștirilebilmesini sağlama \\
\hline & & $\begin{array}{l}\text { Eğitim yaşamında sorgulama becerisi geliştirecek } \\
\text { olması }\end{array}$ \\
\hline & & Bilinçli öğrenciler yetiştirebilecek olma \\
\hline & \multirow{4}{*}{$\begin{array}{c}\text { Öğrenme İsteğine } \\
\text { İlişkin Bireysel } \\
\text { Beceri ve } \\
\text { Düşüncelere Yönelik } \\
\text { Nedenler }\end{array}$} & Sorgulamaya ve düşünmeye dayalı olması \\
\hline & & Yenilikleri görme firsatı yaratması \\
\hline & & Kendi düşüncesiyle örtüşmesi \\
\hline & & Sanat gibi eleştiri içermesi \\
\hline
\end{tabular}

Öğretmen adaylarının tamamı eleştirel pedagojiye yönelik konuları öğrenmek istediklerini belirtmişlerdir. Bu temada, öğrenme isteğine ilişkin eğitime yönelik nedenler ve bireysel beceri ve düşüncelere yönelik nedenler olmak üzere iki alt tema oluşturulmuştur. Öğrenme isteğine ilişkin eğitime yönelik nedenler kapsamında öğretmenlikte yaklaşıma yönelik uygulamalar yapacak olma, ögretmenlikte yararlı olacak ve öğretmenlerin sahip olması gereken bir yaklaşım, ezberci öğretmen adaylarının kalıp dışına çıkabilecek olması, eğitim yaşamında sorgulama becerisi geliştirecek olması, eğitimin geliştirilebilmesini sağlama ve bilinçli öğrenciler yetiştirebilecek olmaya yönelik altı görüş sunmuşlardır. Bu bağlamda GSÖ5, "Bu konuşmayl yapmak da benim için çok faydalı oldu bile şu anda. $O$ anlamda da ben kendi adıma da ögretmenliğe başladığım zaman bunu uygulamak isterim. Çünkü daha detaylı bilmek isterim. O yüzden de yani biraz daha temelleri oturmuş olur böylece düşüncem daha yere să̆lam basar. Bu anlamda da çok faydalı olur diye düşünüyorum." diyerek öğretmenlikte yaklaşıma yönelik uygulamalar yapacağını dile getirmiştir. GSÖ4 ise "Ezberci eğitim anlayışına sahip arkadaşların bilgi edinmesi açısından iyi olur. Çünkü bütün ögretmen adayları aynı zihniyette yetişmiyor. Öncesinden aldiğı ezberci eğitimi üniversitede de devam ettiriyor. Ve bunu kendi yapıyor. Üniversite ortamında biraz daha kalıpların dışında olması gerekiyor, ama o kabuğu kendi yaratıyor ve içinde devam ediyor." diyerek ezberci öğretmen adaylarının kalıp dışına çıkabilecek olmasından söz etmiştir. Öğrenme isteğine ilişkin bireysel beceri ve düşüncelere yönelik nedenler alt teması kapsamında ise sorgulamaya ve düşünmeye dayalı olması, yenilikleri görme firsatı yaratması, kendi düşüncesiyle örtüşmesi ve sanat gibi eleştiri içermesi olmak üzere dört görüş sunmuşlardır. Öğretmen adaylarının eleştirel pedagojiye yönelik konuları öğrenmenin olası etkilerine yönelik görüşleri Tablo 4 'te verilmiştir. 
Tablo 4

Öğretmen Adaylarının Eleștirel Pedagojiye Yönelik Konuları Öğrenmenin Olası Etkilerine Yönelik Görüşleri

\begin{tabular}{|c|c|c|}
\hline Tema & Alt Temalar & Kodlar \\
\hline \multirow{17}{*}{$\begin{array}{c}\text { Eleştirel } \\
\text { Pedagojiye } \\
\text { Yönelik Konuları } \\
\text { Öğrenmenin Olası } \\
\text { Etkileri }\end{array}$} & \multirow{5}{*}{$\begin{array}{l}\text { Öğrencilere } \\
\text { Yönelik Etkiler }\end{array}$} & Öğrencilerin özgür davranışlarını teşvik edebilme \\
\hline & & Öğrencilerin bireysel gelişimlerine katkı sağlayabilme \\
\hline & & $\begin{array}{l}\text { Farklı düşünebilen } \\
\text { yetiștirebilme }\end{array}$ \\
\hline & & Öğrencilerin farklı isteklerini göz önünde bulundurabilme \\
\hline & & Değişimin aracısı olacak öğrenciler yetiştirme \\
\hline & \multirow{5}{*}{$\begin{array}{c}\text { Öğretmenlik } \\
\text { Mesleğine } \\
\text { Yönelik Etkiler }\end{array}$} & Öğretmenin özgür düşünebilmesi \\
\hline & & Öğretim programının dışına çıkabilme \\
\hline & & $\begin{array}{l}\text { Araştırma ve sorgulama becerisi geliştiren etkinlikler } \\
\text { yapabilme }\end{array}$ \\
\hline & & Öğretmenin sürekli kendini geliştirme ihtiyacı duyabilmesi \\
\hline & & Bir öğretmen olarak farkındalık kazanabilme \\
\hline & \multirow{7}{*}{$\begin{array}{c}\text { Öğretmenin } \\
\text { Bireysel } \\
\text { Yaşamına } \\
\text { Yönelik Etkiler }\end{array}$} & Sorgulama becerisi kazanma \\
\hline & & Farklı bakış açıları kazanma \\
\hline & & Ailesindeki çocuklara katkı sağlayabilme \\
\hline & & Özgür düşünme ve hareket etme becerisi kazanma \\
\hline & & Yaratıcılığı geliştirme \\
\hline & & Öğrenme isteğini arttırma \\
\hline & & $\begin{array}{l}\text { Sorgulayarak eksiklikleri belirlemenin bireyde huzursuzluk } \\
\text { yaratabilmesi }\end{array}$ \\
\hline
\end{tabular}

Eleştirel pedagojiye yönelik konuları öğrenmenin olası etkileri teması altında, öğrencilere yönelik etkiler, öğretmenlik mesleğine yönelik etkiler ve öğretmenin bireysel yaşamına yönelik etkiler olmak üzere üç alt tema oluşturulmuştur. Öğrencilere yönelik etkiler kapsamında, öğrencilerin özgür davranışlarını teşvik edebilme, öğrencilerin bireysel gelişimlerine katkı sağlayabilme, farklı düşünebilen ve sorgulayabilen öğrenciler yetiștirebilme, öğrencilerin farklı isteklerini göz önünde bulundurabilme ve değişimin aracisı olacak öğrenciler yetiştirmeye yönelik görüşler sunulmuştur. Bu alt temaya yönelik GSÖ4, "Şu şekilde olur; bunun bilinciyle hareket edersem, öncesinde o özgürlüğ̈̈ kendi kafamda yaşarım ve sonrasında bunu ögrencilerime de aktarırım. Onlarda özgür bir ortama yerleşmiş olur... Daha özgür, daha klsıtlanmamış bir ortamda daha yaratıcı şeyler çıkar. Özellikle kendi alanım için söyleyebilirim. Hani öğrenciyi kısıtlamazsak ĕger, kendi iç dünyasında uçan filler, ne biliyim koşan balıklar vardır ve onların resimlerini görmeye başlarız artık. " diyerek öğrencilerin özgür davranışlarını teşvik edebilmesini vurgulamıştır. Öğretmenlik mesleğine yönelik etkiler kapsamında öğretmenin özgür düşünebilmesi, öğretim programının dışına çıkabilme, araştırma ve sorgulama becerisi geliştiren etkinlikler yapabilme, öğretmenin sürekli kendini geliştirme ihtiyacı duyabilmesi ve bir öğretmen olarak farkındalık kazanabilmeye yönelik görüşler sunulmuştur. Bu bağlamda GSÖ2, "Ders programı içerisinde, müfredatta olanın dışında başka bir aktivite de yapabilirim... Mesela müfredatın dışına çıkılmıyor hiçbir şekilde. Onu yapıp aynı zamanda diğer şeylere de vakit ayırmayı belki göz önüne alabilirim. $O$ açıdan yararlı olur." diyerek öğretim programında esneklik yapabilmekten söz etmiştir. Öğretmenin bireysel yaşamına yönelik etkiler alt teması kapsamında ise, sorgulama becerisi kazanma, farklı bakış açıları kazanma, ailesindeki çocuklara katkı sağlayabilme, özgür düşünme ve hareket etme becerisi kazanma, yaratıcılığı geliştirme, öğrenme isteğini arttırma ve sorgulayarak eksiklikleri belirlemenin bireyde huzursuzluk yaratabilmesine yönelik görüşler sunulmuştur. Sorgulama becerisi kazanmaya yönelik GSÖ7 görüşlerini şu şekilde açıklamıştır: "Kendi öğrenim döneminizde öğrenim açlı̆̆ınızı arttırırsınız. Yani mesela bir tabloyu kimin yaptı̆̆ını öğrenirseniz aynı tarzda başka biri yapmış mı diye araştırabilirsiniz. Veya kendi sisteminizde yanlış var mı bunu araştırabilirsiniz. Mesela bir öğretmen size bir şey anlatmaya başlad, acaba doğrumu anlatıyor diye düşünürsüz yanlı̧ mı anlatıyor diye düşünürsünüz, verdiği örnekleri doğru mu verdi diye düşünürsünüz. Çünkü hep 
karşınızdakini de test etmeye yani doğruluğu var mı yok mu, yararlı mı değil mi, onları yaparsınız veya öğrendiğiniz şeyin sizin ne işinize yarayacă̆ını öğrenebilirsiniz.” Öğretmen adaylarının öğretmen eğitiminde eleştirel pedagojiye yönelik konulara yer verilmesine ilişkin önerileri Tablo 5'te sunulmuştur.

Tablo 5

Öğretmen Adaylarının Öğretmen Ĕ̆itiminde Eleştirel Pedagojiye Yönelik Konulara Yer Verilmesine İlişkin Önerileri

\begin{tabular}{|c|c|c|}
\hline Tema & Alt Temalar & Kodlar \\
\hline \multirow{16}{*}{$\begin{array}{l}\text { Öğretmen } \\
\text { Eğitiminde } \\
\text { Eleştirel } \\
\text { Pedagojiye } \\
\text { Yönelik Konulara } \\
\text { Yer Verilmesine } \\
\text { İlişkin Öneriler }\end{array}$} & \multirow{5}{*}{$\begin{array}{c}\text { Dersi } \\
\text { Düzenlemeye } \\
\text { Yönelik } \\
\text { Öneriler }\end{array}$} & Ayrı bir ders olarak verilmeli \\
\hline & & $\begin{array}{l}\text { Eleştirel pedagojiye yönelik konular bütün bölümlerde } \\
\text { öğretilmeli }\end{array}$ \\
\hline & & Tüm derslere yayılmalı, tek dersle sınırlandırılmamalı \\
\hline & & $\begin{array}{l}\text { Derslerde eleştirel pedagojiye yönelik konulara daha fazla } \\
\text { yer verilmeli }\end{array}$ \\
\hline & & Tüm derslerin merkezinde eleştirel pedagoji olmalı \\
\hline & \multirow{5}{*}{$\begin{array}{c}\text { Dersi } \\
\text { Yürütmeye } \\
\text { Yönelik } \\
\text { Öneriler }\end{array}$} & $\begin{array}{l}\text { Öğretim elemanları eleştirel pedagojiye yönelik bilgi sahibi } \\
\text { olmalı }\end{array}$ \\
\hline & & $\begin{array}{l}\text { Dersi eleştirel pedagojiye yönelik çalışmalar yapan öğretim } \\
\text { elemanları yürütmeli }\end{array}$ \\
\hline & & Dersi aktif ve enerjik öğretim elemanları yürütmeli \\
\hline & & Detaylı ve kapsamlı sekilde yürütülmeli \\
\hline & & Dersin işlenişine yönelik öğrenci görüşlerine başvurulmalı \\
\hline & \multirow{6}{*}{$\begin{array}{c}\text { Derste } \\
\text { Kullanılacak } \\
\text { Yöntem ve } \\
\text { Tekniklere } \\
\text { Yönelik } \\
\text { Öneriler }\end{array}$} & Tartışma teknikleri kullanılmalı \\
\hline & & Sorgulama becerisini geliștirici etkinlikler düzenlenmeli \\
\hline & & Örnek olay ve beyin firtınası yöntemleri kullanılmalı \\
\hline & & $\begin{array}{l}\text { Tek tipliliğin farkına varılmasını ve eleştirel düşünmeyi } \\
\text { sağlayacak etkinlikler düzenlenmeli }\end{array}$ \\
\hline & & Öğretmen adayları kendi yaklaşımlarını sunmalı \\
\hline & & Düz anlatım dıșındaki yöntemler kullanılmalı \\
\hline
\end{tabular}

Öğretmen eğitiminde eleştirel pedagojiye yönelik konulara yer verilmesine ilişkin öneriler, dersi düzenlemeye yönelik öneriler, dersi yürütmeye yönelik öneriler ve derste kullanılacak yöntem ve tekniklere yönelik öneriler olmak üzere üç alt temada incelenmiştir. Dersi düzenlemeye yönelik öneriler kapsamında altı ögretmen adayı ayrı bir ders olarak verilmesi gerektiğini belirtirken iki ögretmen adayı ise eleştirel pedagoji konusunun tüm derslere yayılması, tek dersle sınırlandırılmaması gerektiğini dile getirmiştir. Bu bağlamda GSÖ5, "Yani bence tek başına bir ders olması çok daha iyi olacaktır. Çünkü zaten pek çok formasyon dersinde konular üst üste binmiş durumda ve diyelim ki bir hafta gelmedin okula ve o hafta eleştirel pedagoji anlatıldı ve dolayısıly sen kaçırdın ve bunu daha sonra tek başına ögrenmen yerine bu konuya dair dolu dolu düşünceleri olan bir hocayla tartışarak ögrenmen çok daha verimli olacaktır. Dolayısıyla bir iki hafta gibi bir süreye sıkıştırılmaması gerektiğini de düşünüyorum." diyerek eleştirel pedagoji konusuna yönelik ayrı bir ders olması gerektiğini belirtmiştir. Yine bu alt tema kapsamında eleştirel pedagojiye yönelik konuların bütün bölümlerde öğretilmesine, derslerde eleştirel pedagojiye yönelik konulara daha fazla yer verilmesine ve tüm derslerin merkezinde eleştirel pedagoji olmasına yönelik görüşler de sunulmuştur. Bu bağlamda GSÖ3, "Sadece bizim bölümümüz için değil, genel olarak verilmeli bence." diyerek eleştirel pedagojiye yönelik konuların bütün bölümlerde öğretilmesi gerektiğini dile getirmiştir. Dersi yürütmeye yönelik öneriler kapsamında, öğretim elemanlarının eleştirel pedagojiye yönelik bilgi sahibi olması, dersi eleştirel pedagojiye yönelik çalışmalar yapan öğretim elemanlarının yürütmesi, dersi aktif ve enerjik öğretim elemanlarının yürütmesi, dersin detaylı ve kapsamlı şekilde yürütülmesi ve dersin işlenişine yönelik öğrenci görüşlerine başvurulmasına yönelik görüşler sunulmuştur. Derste kullanılacak yöntem ve tekniklere yönelik öneriler alt temasında ise, tartışma tekniklerinin kullanılmasına, sorgulama becerisini geliştirici etkinliklerin düzenlenmesine, örnek olay ve beyin firtınası yöntemlerinin kullanılmasına, tek tipliliğin farkına varılmasını ve eleştirel düşünmeyi sağlayacak etkinliklerin düzenlenmesine, öğretmen 
adaylarının kendi yaklaşımlarını sunmasına ve düz anlatım dışındaki yöntemlerin kullanılmasına yönelik görüşler sunulmuştur. Derste düz anlatım dışındaki yöntemlerin kullanılmasına yönelik GSÖ7 görüşlerini şu şekilde aktarmıştır: "Bu ders düz anlatılırsa ben öğrenmezdim ... Ama bildiğim bir şey var düz anlatımla anlatılacak bir ders değill." Öğretmen adaylarının görsel sanatlar ve eleştirel pedagoji arasındaki ilişkiye yönelik görüşleri Tablo 6'da sunulmuştur.

Tablo 6

Öğretmen Adaylarının Görsel Sanatlar ve Eleştirel Pedagoji Arasındaki IIlişkiye Yönelik Görüşleri

\begin{tabular}{|c|c|c|}
\hline Tema & Alt Temalar & Kodlar \\
\hline \multirow{6}{*}{$\begin{array}{c}\text { Görsel Sanatlar } \\
\text { ve Eleştirel } \\
\text { Pedagoji } \\
\text { Arasındaki } \\
\text { İlişki }\end{array}$} & \multirow{5}{*}{$\begin{array}{c}\text { Nitelikleri } \\
\text { Açısından } \\
\text { Benzerlikler }\end{array}$} & İkisinin de temelinde eleştiri olmas1 \\
\hline & & İkisinin de sorgulamaya dayalı olması \\
\hline & & İkisinin de özgürlüğe dayalı olması \\
\hline & & İkisinin de durumlara farklı açılardan yaklaşması \\
\hline & & İkisinin de başkaldırı barındırması \\
\hline & $\begin{array}{l}\text { Görsel Sanatların } \\
\text { Niteliği }\end{array}$ & $\begin{array}{l}\text { Görsel sanatların yetenek gerektirmesi ve tartış1lması } \\
\text { gereken bir konu olması }\end{array}$ \\
\hline
\end{tabular}

Tablo 6' da görüldüğü üzere öğretmen adaylarının görsel sanatlar ve eleştirel pedagoji arasındaki ilişkiye yönelik görüşleri temasında nitelikler açısından benzerlikler ve görsel sanatların niteliği olmak üzere iki alt tema oluşturulmuştur. Nitelikler açısından benzerlikler kapsamında ikisinin de temelinde eleştiri olması, ikisinin de sorgulamaya dayalı olması, ikisinin de özgürlüğe dayalı olması, ikisinin de durumlara farklı açılardan yaklaşması ve ikisinin de başkaldırı barındırmasına yönelik görüşler yer almaktadır. $\mathrm{Bu}$ bağlamda GSÖ6, "Direk sanatla dersek sanat zaten aykırı bir şekilde yükselmiştir... Yani başkaldırıdan dolayı yükselmiştir sanat. Burada da bir karşı çıkış var aslında. Bu yüzden ben öyle bağlantı kurdum." diyerek hem görsel sanatların hem de eleştirel pedagojinin başkaldırı barındırmasından benzerlik gösterdiğini belirtmiştir. İkisinin de temelinde eleştiri olmasına yönelik GSÖ5, "Sanat kendi başına muhalif olan bir şeydir. Direk kabullenmek yerine yeni şeyler yaratmaya ve yeni pencereler oluşturmaya çalışllır. Dolayıslyla güzel sanatlar eğitimi verecek olan her ögretmenin ve bu eğitimi alan her öğrencinin de aynı şekilde bu eleştiriden nasibini alması gerekir. Nasıl eleş̧tirel düşüneceğini öğrenmesi adına en başta yani. Dolayısıyla da dediğim gibi sanat kendi başına eleştirel olduğu için zaten sanat ĕgitimi de eleştirel pedagoji ile ister istemez ilişkili olmak durumunda. " diyerek görüşlerini belirtmiştir. İkisinin de sorgulamaya dayalı olmasıyla ilgili ise GSÖ4, "Temelde galiba sorgulamalara dayalı ve var olan içinden pragmatik açıdan çekiliyor bu konular, ben böyle görüyorum hani daha faydalı nasıl olur, konular daha nasıl işlenir, gerekli olan gereksiz olan nedir ona göre ayrım yapılır." şeklinde görüşlerini sunmuştur. Görsel sanatların niteliği kapsamında ise görsel sanatların yetenek gerektirmesi ve tartışılması gereken bir konu olmasına yönelik bir görüş yer almaktadır. Bu görüşe yönelik GSÖ3 görüşlerini şu şekilde aktarmıştır: "Güzel sanatlar eğitimi diğer eğitimlerden biraz farklı çünkü diğerlerinde daha çok sözel bilgiler var ama burada genel olarak senin öğrencinin yeteneği ön planda. Bu yüzden arada öğretim açısından farklılıklar var. Bu nedenle aslında tartı̧̧maya daha açık bir konu diğerlerine göre daha farklı olduğu için. Sadece resim değil mesela müzik de keza yine öyle, güzel sanatları kapsarsak. O nedenle ögretme şekilleri üzerinde tartışmaya çok açık bir konu olduğu için daha alakalı daha yakın diye düşünüyorum."

Araştırmada görsel sanatlar eğitimine yönelik çeşitli eleştirilerde de bulunmuşlardır. Bu eleştiriler Tablo 7 'de sunulmuştur: 
Tablo 7

Görsel Sanatlar Eğitimine Yönelik Eleştiriler

\begin{tabular}{|c|c|c|}
\hline Tema & Alt Temalar & Kodlar \\
\hline \multirow{11}{*}{$\begin{array}{c}\text { Görsel Sanatlar } \\
\text { Eğitimine } \\
\text { Yönelik } \\
\text { Eleştiriler }\end{array}$} & \multirow{9}{*}{$\begin{array}{c}\text { Ilköğretim ve } \\
\text { Ortaöğretim } \\
\text { Düzeyine Yönelik } \\
\text { Eleştiriler }\end{array}$} & Görsel sanatlar ders saatinin az olmas1 \\
\hline & & Öğrencilere özgürlük verilmemesi ve sınırlandırılmas1 \\
\hline & & $\begin{array}{l}\text { Görsel sanatlar dersinde öğrenci seviyesinin dikkate } \\
\text { alınmaması }\end{array}$ \\
\hline & & Öğretmenlerin sergi etkinlikleri yapmamaları \\
\hline & & Öğrencilerin derse yönelik söz hakkının olmaması \\
\hline & & Öğrencilerin dersi boş ders olarak görmeleri \\
\hline & & İki boyutlu resimler dışında etkinlik yapılamamas \\
\hline & & Alan uzmanı olmayan öğretmenlerin dersi yürütmesi \\
\hline & & $\begin{array}{lllll}\begin{array}{l}\text { Öğretmenlerin } \\
\text { eleştirmemeleri }\end{array} & \text { eğitim } & \text { sistemini } & \text { ve } & \text { kendilerini } \\
\end{array}$ \\
\hline & \multirow{2}{*}{$\begin{array}{c}\text { Yükseköğgretim } \\
\text { Düzeyine Yönelik } \\
\text { Eleştiriler }\end{array}$} & $\begin{array}{l}\text { Seviye olarak ilerlenmeden üst düzey kazanımlara yer } \\
\text { verilmesi }\end{array}$ \\
\hline & & $\begin{array}{l}\text { Resim-iş öğretmenliği programına } \text { girişte } \text { merkezi } \\
\text { sınavın etkisinin olması }\end{array}$ \\
\hline
\end{tabular}

Tablo 7'de görüldüğü üzere görsel sanatlar eğitimine yönelik eleştiriler, ilköğretim ve ortaöğretim düzeyine yönelik öneriler ve yükseköğretim düzeyine yönelik öneriler olmak üzere iki alt temada toplanmıştır. İlköğretim ve ortaöğretim düzeyine yönelik eleştiriler kapsamında görsel sanatlar ders saatinin az olması, öğrencilere özgürlük verilmemesi ve sınırlandırılması, görsel sanatlar dersinde öğrenci seviyesinin dikkate alınmaması, öğretmenlerin sergi etkinlikleri yapmamaları, öğrencilerin derse yönelik söz hakkının olmaması, öğrencilerin dersi boş ders olarak görmeleri, iki boyutlu resimler dışında etkinlik yapılamaması, alan uzmanı olmayan öğretmenlerin dersi yürütmesi ve öğretmenlerin eğitim sistemini ve kendilerini eleştirmemelerine yönelik görüsslerini sunmuşlardır. $\mathrm{Bu}$ alt tema kapsamında GSÖ6, "Resim eğitimi çok önemli bir eğitim. Türkiye'de diyor ki "Sen kimya öğretmenisin sen resime de girersin diyor”, yani ne kadar kaldırıp atılmış bir ders. Ya da başka başka bir şey giriyor ya da ücretli ögretmenle geçiştiriliyor. Zaten haftada 1 saat." diyerek hem alan uzmanı olmayan öğretmenlerin dersi yürütmesine hem de görsel sanatlar ders saatinin az olmasına değinmiştir. GSÖ7, “...Sanat dediğiniz şey sadece iki boyutlu eserler değildir. Mesela siz hiç bir devlet okulunda bana göre, $\% 99$ 'luk bir kısımda, gidip de çocuklara heykel çalışmast yaptıramazsınız. Yani kille uğraştıramazsınız. Çocuklar kili bilmez işte yağlı boya yaptıramazsınız hem ülke ekonomisinin, gelen çocukların bütçeleri, araç gereçlerin pahalılı̆̆l. Hem onu yapacak ortamınız mevcut değil. Yani her okulun atölyesi yok. Sınıf ortaminda yağlı boya çok zor. Şövaleler gerekir falan yapamazsınız.” diyerek iki boyutlu resimler dışında etkinlik yapılamamasından söz etmiştir. Bu kapsamda GSÖ3, "Yine aynı şey mesela bir öğrenciye bir boyanın nasıl kullanıldı̆̆ını, nerde nasıl olduğunu ya da nasil bir tarzla yapılması gerektiğini göstermeden ya da bir şeyin nasıl çizildiğini göstermeden, bir ön bilgi vermeden direk bir şeyi yaptırmaya kalkıştı̆̆ınızda çoğu zaman öğrenci afallar, yapamaz ve ondan sonraki hayatında da ben çizemiyorum diye devam eder. O yüzden mesela onun seviyesine göre başlamak her zaman daha iyidir. Çoğu zaman böyle olmuyor.” diyerek görsel sanatlar dersinde öğrenci seviyesinin dikkate alınmamasına yönelik görüşünü sunmuştur. Öğrencilere özgürlük verilmemesi ve sınırlandırılmasına yönelik ise GSÖ5 görüşlerini şu şekilde aktarmıştır: "Yani mevcut sistemde açıkçası çok da sanat eğitimi diyebileceğimiz bir şey olduğunu düşünmüyorum ben. Daha çok hadi 19 Mayls geldi, hadi 19 Mayısa dair resim yapın, 23 Nisan'da ona dair bir resim yapın ya da tatilde ne yaptıniz, ona dair bir resim yapın şeklinde ve müfredatın da biraz getirisiyle bunların dışına çıkamıyor ögretmenler ya da çıkmayı tercih etmiyorlar bilmiyorum. Dolaylstyla ister istemez sürekli konular birbirini tekrar ediyor ve hiçbir ögretmen ve hiçbir öğrenci yeni bir şey, yaratıcı bir şey yapmaya çalışmıyorlar bu süreçte." Yükseköğretim düzeyine yönelik eleştiriler kapsamında ise, seviye olarak ilerlenmeden üst düzey kazanımlara yer verilmesi ve resim-iş öğretmenliği programına girişte merkezi sınavın etkisinin olmasına yönelik eleştirilerde bulunmuşlardır. 


\section{Sonuç, Tartışma ve Öneriler}

Araştırmanın sonuçları doğrultusunda, öğretmen adaylarının eleştirel pedagoji yaklaşımını genel olarak eğitim sistemleri açısından gerekli gördükleri belirlenmiştir. Bunun yanı sıra, eleştirel pedagoji yaklaşımına yönelik kendi bakış açıları bağlamında da olumlu görüşlere sahip oldukları belirlenmiştir. $\mathrm{Bu}$ kapsamda yapılan çalışmalar incelendiğinde öğretmen adaylarının eleştirel pedagoji ilkelerine katılım düzeylerinin orta düzeyde olduğunu belirlenmiștir (Kozikoğlu \& Erden, 2018; Şahin, Demir \& Arcagök, 2016; Yılmaz \& Altınkurt, 2011). Bu çalışmada ise nispeten daha farklı bir sonuca ulaşıldığı söylenebilir. Çünkü araştırmaya katılan tüm öğretmen adayları eleştirel pedagoji yaklaşımına yönelik olumsuz bir görüş sunmamışlar aksine bu yaklaşımı benimsediklerini, belirttikleri olumlu görüşlerle yansıtmışlardır. Söz konusu bu çalışmalarla farklı bir sonuca ulaşmanın nedeninin, araştırmaya dahil edilen öğretmen eğitimi programıyla ilgili olduğu düşünülmektedir. Zira katılımcı öğretmen adaylarının eleştirel pedagojiyle görsel sanatlar arasında nitelik açısından ilişki ve benzerlik olduğunu da dile getirmişlerdir. Görsel sanatlar ile eleştirel pedagoji yaklaşımı arasında ilişkiye yönelik görüşler kapsamında nitelik açısından ikisinin de temelinde eleştiri, sorgulama, özgürlük, farklı bakış açılarıyla yaklaşma ve başkaldırı barındırmasından söz edilmiştir. Buradan yola çıkılarak, görsel sanatlar ögretmen adaylarının eleştirel pedagoji yaklaşımını genel olarak benimsedikleri söylenebilir. Eleştirel pedagoji yaklaşımını benimseyen öğretmenlerin, eğitim sistemindeki öğelere eleştirel bakış açısıyla yaklaştıkları ve eğitim sistemindeki sorunları belirlemeye ve çözmeye yönelik farkındalıkları (Aksakall1, 2019) göz önünde bulundurulduğunda bu sonucun eğitim sistemi açısından olumlu doğurguları olacağı söylenebilir.

Öğretmen eğitimi açısından eleştirel pedagoji yaklaşımına eğitim fakültesi lisans derslerinde genel anlamda yer verilmediği belirlenmiştir. Bazı öğretim elemanlarının ise derste kısaca değindiklerinden söz edilmiştir. Bir öğretmenin eğitime yönelik her yaklaşımla ilgili bilgi edinmesi, yaklaşımları karşılaştırma ve benimseme açısından önemlidir. Kaldı ki öğretmen adaylarının eleştirel pedagoji yaklaşımını öğrenmek isteyip istemedikleri sorulduğunda, katılımcıların tamamı öğrenmek istediklerini dile getirmişlerdir. $\mathrm{Bu}$ konuyu öğrenmek isteyen öğretmen adaylarına eleştirel pedagojiden bahsedilmemiş olmasının, öğretmen eğitimi programları açısından bir eksiklik olduğu söylenebilir. Eleştirel pedagoji yaklaşımını neden öğrenmek istedikleri sorulduğunda ise öğretmen adayları eğitime yönelik ve bireysel beceri ve düşüncelere yönelik nedenlerden söz etmişlerdir. Eğitime yönelik nedenler kapsamında ise öğretmenlik mesleğinde kendilerine katkı sağlayacağı ve bu bağlamda uygulamalar yapacaklarından söz etmeleri önemli görüşlerdir. Teoride öğrendikleri bir konuyu uygulamaya ve yaşama yansıtacak olmalarını düşünmeleri eleştirel pedagoji yaklaşımını benimsediklerine işaret etmektedir. Eleştirel pedagoji yaklaşımını eğitimin dışında bireysel nedenlerle öğrenmek istemeleri de ayrıca dikkat çekici bir mevzudur. Bu doğrultuda öğretmen adaylarının hem eğitimsel hem de bireysel nedenlerle eleştirel pedagoji yaklaşımını öğrenmek istedikleri söylenebilir. Eleştirel pedagoji yaklaşımını öğrenmenin etkilerine yönelik görüşler bağlamında ise öğrencilere yönelik, öğretmenlik mesleğine yönelik ve öğretmenin bireysel yaşamına yönelik olumlu yönde etkileri olacağ sunulmuştur. Öğrencilere yönelik etkiler kapsamında öğrencilerin düşünme becerileri ve değişimin aracısı olma nitelikleri açısından etkileri olmasından söz edilmiştir. Yine öğretmenlik mesleğinde düşünme becerileri ve yapacakları uygulamalar açısından etkilerine değinilmiştir. Bireysel yaşama yönelik olarak ise yine düşünme becerileri ve çevresine de yansıtma bağlamında görüşlerin yer aldığı belirlenmiştir.

Eleştirel pedagoji konusunun öğretmen eğitimi programlarında yer verilmesine yönelik öğretmen adaylarının çoğunun ayrı bir ders olarak tasarlanmasına ilişkin görüşleri önem taşımaktadır. Eleştirel pedagojiye yönelik Türkiye'de yapılan çalışmalarda eleştirel pedagojiye yönelik lisans düzeyinde, lisansüstü düzeyde ve hizmet içi eğitim bağlamında eğitim ve derslerin eklenmesine yönelik benzer önerilerde bulunulmuştur (Balcı \& Kocabaş, 2020; Kozikoğlu \& Erden, 2018; Sarıgöz \& Özkara, 2015). Mevcut eğitim sisteminin ve okulların eleştirel pedagojinin öngördüğü çoğulcu, eleştirel, özgürleştirici, demokratik, adil, dönüştürücü rollerinden uzak olduğunu belirleyen araştırmaların sonuçları doğrultusunda (Kesik \& Bayram, 2015) öğretmen eğitiminde bu dersin eklenmesi okulların niteliklerinin iyileştirilmesi açısından da katkılar sağlayabilecektir. Bu açıdan öğretmen eğitiminde Eleştirel Pedagoji dersine yönelik planlamalar yapılmasının önem taşıdı̆̆ 1 söylenebilir. Öğretmen adaylarının bu konunun sadece görsel sanatlar eğitimi açısından değil öğretmen eğitimi programlarının hepsinde yer verilmesi gerektiğini düşünmeleri de önemlidir. Ayrı bir ders olarak okutulduğunda ise 
dersin yürütülmesi kapsamında daha çok öğretim elemanına yönelik önerilerde bulunmuşlardır. Derste kullanılacak yöntem ve teknikler kapsamında ise öğretme-öğrenme sürecini çeşitlendirmeye yönelik görüşler sunulmuştur. Öğretmen adaylarının yeniliklere açık, özgür düşünebilen ve sorgulayabilen bireyler olarak yetişmeleri için düzenlemeler yapılması önerilmektedir (Kozikoğlu \& Erden, 2018). Özgür düşünme, sorgulama ve eleştirel düşünme gibi becerileri odağına alan eleştirel pedagoji yaklaşımının öğretiminde de çeşitlilik içeren ve özgür düşünmeyi barındıran etkinlik ve uygulamaların yapılması önem taşımaktadır.

Araştırmada eleştirel pedagoji yaklaşımının dışında dikkat çekici ve önemli görülen bazı sonuçlara da ulaşılmıştır. Görsel sanatlar eğitiminde mevcut sorunlara değinildiğinden bu görüşlere de yer verilmesinin sorunların dile getirilmesi açısından yararlı olacağı düşünülmektedir. İlköğretim ve ortaöğretim düzeyinde görsel sanatlar ders saatinin çok az olmasından, görsel sanatlar dersinde öğrencilerin sınırlandırılmasından, seviyelerinin göz ardı edilmesinden, etkinlik çeşidinin azlığından, bazı okullarda dersin alan öğretmenleri tarafindan yürütülmemesinden ve öğretmenlerin sergi etkinlikleri yapmamalarından söz edilmiştir. Yükseköğretim düzeyinde ise programa girişte merkezi sınavının etkisinin olmasına ve seviye olarak ilerlenmeden üst düzey kazanımlara yer verilmesine yönelik eleştirilerde bulunulmuştur. Öğretmen adaylarının belirttikleri bu eleştiri ve sorunlar görsel sanatlar eğitimine yönelik yapılan çeşitli araştırmalarda da yer almaktadır (Ayaydın, 2011; Çakmak \& Türkcan, 2019; Yazar, Aslan \& Şener, 2014). Bu açıdan araştırmaya katılan öğretmen adaylarının görsel sanatlar eğitiminde karşılaşılan sorunlara yönelik farkındalıkları olduğu söylenebilir.

Araştırmanın sonuçları doğrultusunda, öğretmen eğitimi programlarına Eleştirel Pedagoji dersinin konulabileceği önerilmektedir. Bu çalışma sadece görsel sanatlar eğitimi kapsamında ve sınırlı sayıda katılımcıyla gerçekleştirilmiştir. Benzer çalışmalar farklı öğretmen eğitimi programlarında öğrenim görmekte olan öğretmen adaylarıyla da yürütülebilir. Eğitim araştırmaları bağlamında eleştirel pedagojiye yönelik daha fazla sayıda ve derinlemesine araştırmalar yapılarak sonuçların mevcut eğitim sistemiyle bütünleştirilmesine yönelik benzer öneriler de (Balcı \& Kocabaş, 2020) bulunmaktadır. Eleştirel pedagoji konusunu öğrenmeye yönelik öğretim elemanları, öğretmenler, öğretmen adayları ve yöneticilerin de dahil edildiği daha geniş kapsamlı bir ihtiyaç analizi araştırması gerçekleştirilebilir. Bunun yanı sıra, görsel sanatlar eğitimine yönelik, ilköğretim, ortaöğretim ve yükseköğretim düzeyindeki sorunlar araştırılarak bu sorunlara yönelik çözüm önerileri geliştirilebilir.

\section{Kaynakça}

Aksakallı, A. (2019). Eleştirel pedagojiye yönelik öğretmenlerin eğitim inançları. Eğitimde Nitel Araştırmalar Dergisi, 7(2), 583- 605. DOI: 10.14689/issn.2148-2624.1.7c.2s.6m

Aslan, Ö. M. (2014). Eğitim felsefesi dersinin okul öncesi öğretmen adaylarının felsefi tercihlerine ve eleştirel pedagojiye yönelik görüşlerine olan etkisi. Electronic Journal of Social Sciences, 13(48), 1-14.

Ayaydın, A. (2011). Resim-iş öğretmeni yetiştirme programı ile görsel sanatlar dersi öğretim programı arasındaki uyum sorunları. Çukurova Üniversitesi Ĕ̈itim Fakültesi Dergisi, 40(3), 26-33.

Balcı, A. T. \& Kocabaş, A. (2020). Sınıf öğretmenlerinin eleştirel pedagoji ilkelerine katılım düzeyleri. Eğitimde Kuram ve Uygulama, 16(1), 53-68.

Büyükgöze, H. \& Fındık, L. Y. (2018). Eleştirel pedagojinin eğitim sistemindeki görünümü: Öğretmenler üzerine bir çalışma. İlköğretim Online, 17(3), 1336-1352.

Büyüköztürk, Ş., Kılıç Çakmak, E., Akgün, Ö. E., Karadeniz, Ş. \& Demirel, F. (2011). Bilimsel araştırma yöntemleri (10. Bask1). Ankara: Pegem Akademi.

Çakmak, N. \& Türkcan, B. (2019). Değişmeyen algılar, değişmeyen sorunlar: Öğrenci-öğretmen-veli bağlamında ilkokul görsel sanatlar dersi. Eğitimde Nitel Araştırmalar Dergisi, 7(2), 768-791.

Freire, P. (1985). Reading the world and reading the word: An interview with Paulo Freire. Language Arts, 62(1), 15-21.

Giroux, H. A. (2010). Rethinking education as the practice of freedom: Paulo Freire and the promise of critical pedagogy. Policy Futures in Education, 8(6), 715-721.

Giroux, H. A. \& Giroux, S. S. (2006). Challenging neoliberalism's new world order: The promise of critical pedagogy. Cultural studies? Critical methodologies, 6(1), 21-32.

Güven, M. \& Aytekin, C. A. (2016). Resim öğretmeni adaylarının eleştirel pedagoji, kitsch olgusu ve estetik beğeni ile ilgili görüşleri. Uluslararası Ĕgitim Bilimleri Dergisi, 3(7), 49-64. 
İşler, A. Ş. (2005). İlköğretimin ilk yıllarındaki sanat eleştirisi uygulamaları ve bu uygulamaların eleştirel düşünme gelişimi açısından önemi. Uludă̆ Üniversitesi Eğitim Fakültesi Dergisi, 18(1), 135-149.

Karabulut, N., Karakuzu, M. \& Konca, Y. (2008). Sanat eğitiminde pedagojik eleştiri yöntemleri. Atatürk Üniversitesi Güzel Sanatlar Enstitüsü Dergisi, 21, 87-111.

Kesik, F. \& Bayram, A. (2015). Eğitim sisteminin eleştirel pedagoji perspektifinden bir değerlendirmesi. Mersin Üniversitesi Eğitim Fakültesi Dergisi, 11(3), 900-921.

Kozikoğlu, İ. \& Erden, R. Z. (2018). Öğretmen adaylarının eğitim felsefesi inançları ile eleştirel pedagojiye ilişkin görüşleri arasındaki ilişkinin incelenmesi. İlkögretim Online, 17(3), 15661582.

Mamur, N. (2014). Post-modernizmin sanat eğitimine yansıma biçimleri görsel kültür ve eleştirel pedagoji. Ahi Evran Üniversitesi Kırșehir Eğitim Fakültesi Dergisi, 15(2), 59-77.

McKenna, S. E. (1999) Theory and practice: Revisiting critical pedagogy in studio art education. Art Journal, 58(1), 74-79.

McLaren, P. (2005). Critical pedagogy and class struggle in the age of neoliberal globalization: Notes from history's underside. The International Journal of Inclusive Democracy, 2(1), 1-24.

McMillan, J. H. (2004). Educational research: Fundamentals for the consumer ( $4^{\text {th }}$ Edition). Boston: Pearson.

Mercin, L. \& Alakuş, A. O. (2005). Sanat eleştirisi ve pedagojik eleştiri yönteminin incelenmesi. Dicle Üniversitesi Ziya Gökalp Ĕ̈itim Fakültesi Dergisi, 5, 36-46.

Patton, M. Q. (2002). Qualitative research and evaluation methods ( $3^{\text {rd }}$ Edition). Thousand Oaks: Sage Publications.

Şahin, Ç., Demir, M. K. \& Arcagök, S. (2016). Öğretmen adaylarının eleştirel pedagoji ilkelerine yönelik yaklaşımlarının çeşitli değişkenler açısından incelenmesi. Erzincan Üniversitesi Ĕ̈itim Fakültesi Dergisi, 18(2), 1187-1205.

Sarıgöz, O. \& Özkara, Y. (2015). Öğretmen adaylarının eleştirel pedagoji ve ilkeleri hakkındaki görüşlerinin bazı değişkenler açısından incelenmesi. Uluslararası Sosyal Araştırmalar Dergisi, 8(39), 710-716.

Sönmez, V. \& Alacapınar, F. G. (2011). Örneklendirilmiş bilimsel araştırma yöntemleri. Ankara: Anı Yayınc1lik.

Tavin, K. M. (2003). Wrestling with angels, searching for ghosts: Toward a critical pedagogy of visual culture. Studies in Art Education, 44(3), 197-213.

Varlıkgörücüsü, N. \& Şahin, M. (2018). Radikal felsefe, eleştirel pedagoji ve okulsuz toplum. Eğitim ve Öğretim Araştırmaları Dergisi, 7(3), 75-82.

Yazar, T., Aslan, T. \& Şener, S. (2014). Sanat eğitimi sorunu olarak ülkemizde ilk ve orta öğretim kurumlarında sanat eğitimine olan ilgisizlik sebepleri. Ondokuz Mayıs Üniversitesi Ĕgitim Fakültesi Dergisi, 33(2), 593-605.

Yıldırım, A. (2011). Eleştirel pedagoji - Paulo Freire ve Ivan Illich' in eğitim anlayışı üzerine (2. Baskı). Ankara: Anı Yayıncilik.

Yılmaz, K. \& Altınkurt, Y. (2011). Öğretmen adaylarının eleştirel pedagoji ile ilgili görüşleri. Ahi Evran Üniversitesi Ĕgitim Fakültesi Dergisi, 12(3), 195-213.

Yokley, S. H. (1999). Embracing pedagogy a critical in art education. Art Education, 52(5), 18-24.

\section{Extended Abstract}

\section{Introduction}

Determining the current situation to include the subject of critical pedagogy in teacher education, views of preservice visual arts teachers on critical pedagogy issues and views on learning these issues is important for both visual arts education practices and researches in the field of visual arts. The aim of the research is to determine the willingness and needs of preservice visual arts teachers about learning issues related to critical pedagogy. 


\section{Methodology}

This study is a descriptive research conducted in a qualitative context. Convenience sampling method was used to determine the participants of the study. The participants of the research were selected from the juniors and seniors studying in the department of visual arts education at a state university in the south of Turkey in 2015-2016 academic year. Semi-structured interview technique was used to collect the data of the research. Before the interview, the participants were given detailed information about critical pedagogy. Research data were collected through an interview form developed by the researchers. The data of the research were analysed with the inductive analysis approach. Peer examination technique was used for the reliability of the analysis of the data. Attention was paid to the validity and reliability of the research, as well as to the detailed description and reporting of the research, and to control the researcher effects, researchers tried to avoid prejudices, experiences and tendencies throughout the research.

\section{Findings}

The findings were gathered under seven themes. These themes are: preservice teachers' views on critical pedagogy, views on the inclusion of critical pedagogy in teacher education, views on the willingness to learn issues related to critical pedagogy, views on the possible effects of learning critical pedagogy issues, recommendations regarding the inclusion of critical pedagogy in teacher education, views on the relationship between visual arts and critical pedagogy, criticism towards visual arts education.

\section{Discussion}

In line with the results of the research, it has been determined that preservice teachers consider the critical pedagogy approach necessary in terms of education systems in general. In addition, it has been put forward that they have positive views on the critical pedagogy approach looking from their own perspectives. When the studies conducted in this context are examined, it has been found out that the participation of preservice teachers in the principles of critical pedagogy is at a moderate level (Kozikoğlu \& Erden, 2018; Şahin, Demir \& Arcagök, 2016; Yılmaz \& Altınkurt, 2011). In this study, it can be said that a relatively different result was reached. Because all the preservice teachers participating in the research did not present a negative view towards the critical pedagogy approach, on the contrary, they reflected that they adopted this approach through their positive opinions. It is thought that the reason for reaching a different result with these studies could be linked to the teacher education program included in the research.

In terms of teacher education, it has been determined that the critical pedagogy approach is not generally included in the undergraduate courses of the faculty of education. It was stated that some of the instructors briefly mentioned these issues in the courses. It is important for a teacher to obtain information about each approach to education in order to compare and adopt the approaches. Moreover, when the preservice teachers were asked whether they wanted to learn the critical pedagogy approach, all of the participants stated that they wanted to learn. It can be said that not to mention of critical pedagogy to preservice teachers who want to learn about this issue is a deficiency in terms of teacher education programs.

The views of most of the preservice teachers regarding the inclusion of critical pedagogy in teacher education programs as a separate course are important. In studies conducted in Turkey on critical pedagogy, similar suggestions have been made for the addition of training and courses for critical pedagogy at undergraduate, graduate level and in-service training (Balc1 \& Kocabaş, 2020; Kozikoğlu \& Erden, 2018; Sarıgöz \& Özkara, 2015). In line with the results of studies showing that the current education system and schools are far from the pluralist, critical, liberating, democratic, fair and transformative roles predicted by critical pedagogy (Kesik \& Bayram, 2015), the addition of this course in teacher education will also contribute to improving the quality of schools. ${ }^{i}$

\footnotetext{
' Bu makaleye yazarlar eşit oranda katkı sağlamıştır.
} 